\title{
THE MORAL CLAUSE IN PATENT LAW AND THREATS POSED BY HUMAN GERMLINE GENOME EDITING
}

\author{
Gabriel Zanatta TocchetTo*
}

\begin{abstract}
This article examines whether the lack of closure of moral clauses in patent laws, particularly in dealing with the issue of human germline genome editing, causes such clauses to fail to function as a moratorium in countries like Mexico. The hypothesis posed here is that a general, open, moral clause in intellectual property legislation, specifically in patent lawe, is ineffective when confronted with a foreseeable but strong innovation that alters an area of applied biology such as human germline genome editing. Using the deductive method, this research aims to determine whether countries like Mexico need to provide more specific guidance in their legislation on technological innovations like human germline modification in order to foster an atmosphere of legal certainty. A comparative analysis of the closed morals clause in the European Patent Convention and the open morals clause in Mexico's intellectual property law confirms this hypothesis. Specifically, the lack of closure of a morals clause in patent lawe, when confronted with novel and complex technological advances, will likely fail to function as a moratorium.
\end{abstract}

Keywords: Human Genome, Moratorium, Moral Clause in Patent Law, Mexico.

RESUMEN: Este artículo examina si la falta de cierre de las cláusulas morales en las leyes de patentes, particularmente al tratar el tema de la edición del genoma de la línea germinal humana, hace que tales cláusulas no funcionen como una moratoria en países como México. La hipótesis planteada aquí es que una cláusula moral general abierta en la legislación de propiedad intelectual, específicamente en la ley de patentes, es ineficaz cuando se enfrenta a una innovación fuerte pero previsible que altera un área de la biología aplicada como la edición del genoma de la línea germinal humana. Utilizando el método deductivo, está investigación tiene como objetivo determinar si países como México necesitan brindar

* PhD candidate at PUC Paraná, Master in Law from Faculdade Meridional Imed with a CAPES/FAPERGS scholarship, Post Graduating in Business Law from Estácio. Lawyer. Researcher of the project "The Legal Protection of Open Innovation in New Technologies". Email: gztocchetto@gmail.com. 


\begin{abstract}
una orientación más específica en su legislación sobre innovaciones tecnológicas como la modificación de la línea germinal humana para fomentar un ambiente de certeza jurídica. Un análisis comparativo de la cláusula de moral cerrada en la Convención Europea de Patentes y la cláusula de moral abierta en la ley de propiedad intelectual de México confirma esta hipótesis. Especificamente, la falta de cierre de una cláusula moral en la ley de patentes, cuando se enfrenta a avances tecnológicos novedosos y complejos, probablemente no funcionará como una moratoria.
\end{abstract}

Palabras clave: Genoma Humano, Moratoria, Cláusula Moral en el Derecho de Patentes, México.

Table of Contents

I. INTRODUCTION ........................................................................ 146

II. Basic Concepts of the Autopoietic Systems Theory .................... 147

III. Genetic Editing of the Human Genome as an Important

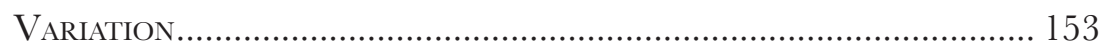

IV. The Meaning of Moral Glause and an Example of Glosure ....... 158

V. Open Moral Glause, the Mexican Example ................................. 164

VI. Gonclusion ......................................................................... 168

\title{
I. INTRODUCTION
}

A technological innovation that has sparked a lot of discussion, scrutiny and broad speculation across the scientific world is CRISPR (Clustered Regularly Interspaced Short Palindromic Repeats), a technology discovered in 2012. Debate has been particularly heated regarding the genetic editing of the human germline. For the first time ever, aside from science fiction caricatures, scientists have created a sufficiently precise, inexpensive, and replicable tool capable of editing the very code that originally led to the appearance of human beings, the DNA.

In the short time that has elapsed since the discovery of this new technology, two babies (as far as official records go) have been born after having had their germline genetically edited, a patent rights case involving two prestigious academic research institutions has been vigorously litigated in court, and an international moratorium on the use of this technology has been proposed and drafted. At the same time, research on somatic cells, that is, cells that divide themselves through mitosis, and don't generate inheritable changes, is happening, and more discoveries are on the way in that field as well. One of the main challenges facing the law will be devising a mechanism that can respond effectively to these rapid changes and serves as a bridge between scientific research and the market. Historically, this has been the domain of Intellectual Property. 
Some researchers argue that existing legislation in many countries already addresses this issue and contain mechanisms designed to deny patent requests for technologies that violate the standard institute of Intellectual Property's moral clause, typically incorporated in patent laws. The question then becomes: Are morals clauses sufficient in facing innovations that involve complex, novel innovations? This article will narrow the focus of this question to an analysis of the effectiveness of morals clauses in dealing with the use of CRISPR technology to genetically alter the human genome. Thus, the specific question posed for the purpose of this article is: Is it possible to verify whether the lack of closure of the moral clause in patent law, particularly when referring to human germline genome editing, acts merely as a general clause of prohibition that, in practice, fails to function as a moratorium?

Answering this question first requires resolving two fundamental, underlying issues. The first issue is whether morality alone is able to provide a sufficient foundation on which to organize a complex society. This is an issue many legal researchers may find easy to answer considering one of the primary reasons the law itself originated was as a consequence of the determination that morality is an insufficient organizing principle given the complexity of modern human society. Nevertheless, this issue will be specifically addressed in Section 4.

The second issue is more complicated and will be evaluated in Section 3. This issue concerns whether human germline genome editing is such a complex subject that it requires a more sophisticated assessment mechanism than a moral scheme alone is able to provide. After consideration of the evidence presented in this text, the moral scheme will be shown to be insufficient.

The hypothesis posed here is that a general, open moral clause in iIntellectual Property legislation, specifically in patent law, is likely to fail when presented with an unprecedented innovation such as human germline genome editing. The method used to test this hypothesis will be the deductive method.

This text will be divided into four principal sections with these corresponding objectives: (1) introduce aspects of the Autopoietic Systems Theory necessary for an understanding of the argument in this article; (2) show how CRISPR technology is an innovation beyond the scope of anything traditional moral clauses have previously had to address; (3) explain moral clauses and how they function, particularly as they apply to an innovation such as CRISPR technology ; and (4), discuss the morals clause in Mexico's legislation and evaluate its capacity to address the issues raised by technological innovations such as CRISPR.

\section{Basic Concepts of the Autopoietic Systems THEORY}

The Autopoietic Systems Theory will be used as the theoretical paradigm. This theory allows incorporation of both dynamic and complex factors into 
the analysis of a system. As applied to the field of legal sociology, this is a significant advantage for an understanding of the issues that will be raised here. The theory is also capable of accounting for external elements which impact the legal system, as will be made clear in the development of this chapter.

To begin, a brief explanation of some of the basic theoretical elements of the Autopoietic Systems Theory is necessary. The theory was developed by the German jurist, Niklas Luhmann, and was inspired by the autopoiesis theory in biology formulated by Chilean researchers, Humberto Maturana and Francisco Varela. ${ }^{1}$ The inspiration came as a factor of modification of an existing theory, Talcott Parsons' Systems Theory, which was itself based on biology.

Parsons' theory considers society to be like an organism comprised of various distinct yet interdependent subsystems, each of which engages in different activities (actions), interdependent and exclusive to systems. ${ }^{2} \mathrm{~A}$ simple example of such interconnected systems are the digestive and circulatory systems of the human body. The two systems perform complementary operations, one absorbs energy from food and the other distributes this energy throughout the body. Each has distinct yet interdependent functions, without one, the other cannot continue to function. For example, without energy, blood will not circulate, and without the energy distribution performed by the circulatory system, there can be no digestion. The two systems are not capable of changing tasks, that is, the circulatory system cannot digest, nor can the digestive system circulate blood. Furthermore, each system acts and reacts according to changing conditions within the overall system. For example, poor circulation can directly affect digestion, and poor digestion can directly affect circulation. For Parsons, these biological systems metaphorically represent the various social systems. Each system acts within the social organism fulfilling its role within the social system ${ }^{3}$ by employing their distinct yet interdependent characteristics.

The fundamental starting point is the concept of social systems of action. The interaction of individual actors, that is, takes place under such conditions that it is possible to treat such a process of interaction as a system in the scientific sense and subject it to the same order of theoretical analysis which has been successfully applied to other types of systems in other sciences $[. .$.$] The frame$ of reference concerns the "orientation" of one or more actors - in the fundamental individual case biological organisms - to a situation, which includes other actors. The scheme, that is, relative to the units of action and interaction, is a relational scheme. It analyzes the structure and processes of the systems

1 Leo Peixoto Rodrigues et al., Niklas Luhmann: A sociedade como sistema 23 (Edipucrs, 2012).

2 Talcott Parsons, The Social System 1 (2. ed. Routledge, Taylor and Francis Group, 2005).

3 Ibid. at 16. 
built up by the relations of such units to their situations, including other units. It is not as such concerned with the internal structure of the units except so far as this directly bears on the relational system. ${ }^{4}$

In creating the Autopoietic Systems Theory, however, Luhmann proposes an important change. He exchanges Parsons' action-based theory for a theory based on communication. For Luhmann, society exists primarily as communication. ${ }^{5}$ Inspired by Maturana and Varela's proposition that the operation between system units (or subsystems) would occur not through action, but by independent interaction, ${ }^{6}$ Luhmann extends the Autopoietic Systemic Theory from biology for the field of sociology.

Maturana and Varela ${ }^{7}$ posit that an individual organism has a dual nature to its functioning. First, it interacts with the world via the transmission of information, that is, by either observing the environment, or influencing it. Second, it interacts with itself through operations within its own systemic limits. For example, a human being can be viewed as a system that communicates with the environment through its sensory capabilities while operating within its cognitive limits. This sensory opening is the means by which a human being understands the world and also allows for modification or adaptation. Thus, a human being is only able to operate directly on factors within its envelope, within its cognitive limit, ${ }^{8}$ and can only generate changes in the external environment - everything outside this envelope indirectly, via influence.

Luhmann calls this envelope "operative closure", and refers to an individual's sensory capacity as the "cognitive opening". Applying these concepts to a legal system means that it operates and is understood within its own system, for example, by defining that system's boundaries. It observes and communicates with everything outside its own system by internalizing information gathered from the external environment and making assessments regarding possible legal implications. The legal system itself is limited to that which constitutes legal communication.

O modo de operação, que o sistema da sociedade produz, e reproduz, é a comunicação provida de sentido. Isso permite dizer que o sistema jurídico, à medida que é um sistema-parte da sociedade, utilizado como modo de operação

4 Ibid. at 1.

5 Niklas Luhmann, Theory of Society: volume 1, 113 (Rhodes Barrett trans. Stanford University Press, 2012).

6 Humberto Maturana, et al., Autopoiesis and cognition: The realization of the liVING XIX-XX (Springer Science \& Business Media, 1991).

7 Humberto Maturana, et al., Autopoiesis and cognition: The realization of the liVING (Springer Science \& Business Media, 1991).

8 Humberto Maturana, et al., Autopoiesis: The organization of living systems, its characterization and a model, 5 (4) Biosystems 187, 196 (1974). 
da comunicação, não pode fazer nada que não seja - como meio do sentido mediante a comunicação - compor formas (sentenças). É trabalho do sistema social possibilitar e tornar isso evidente no curso de uma longa evolução sociocultural. No sistema jurídico, isso funciona como garantia de que, por exemplo, nem papel, nem tinta, nem pessoas, nem outros organismos, nem em tribunais, nem em seus espaços, nem aparelhos telefônicos, nem computador, que ali são utilizados, façam parte do sistema. ${ }^{9}$

The characteristic of operative enclosure is a very important characteristic for the understanding of the Autopoietic Systems Theory and even more important for the development of the present work. First, due to the fact that it defines the autonomy of systems, that is, it defines that in a normal situation only the system that decides on the juridicity of something is the juridical system, while all that this system can do in relation to its environment, is communicating this operation of juridical decision, generating consequences on the environment, but not being able, for example, to judge on the economic viability of a post-legal practice. ${ }^{10}$ Second, because it opens space for understanding systemic evolution, especially the selection stage, which is exactly the step that the present work will assess on the pressures that the moral clause for the protection of intellectual property will suffer on the hands of the economy.

In the Autopoietic Systems Theory, autonomy results from a process of systemic differentiation, or self-differentiation ${ }^{11}$ As society expands and develops, it generates communication complexities such that various systems will eventually differentiate themselves and gain autonomy. An example of this is the social development that has led to the separation of religion from the state.

Today, the normal operation for such communications is that the State organizes and operates politically within its limits, and Religion organizes and operates within its own limits as well. To use a biological analogy, it is as if a single cell, which was on its way of finishing cellular reproduction, but was still interconnected to another cell, had finished the process and each of the

9 Niklas Luhmann, O Direito da Sociedade 46 (Saulo Krieger trans., Martins Fontes, 2016) (1993). Free translation: The modus operandi, which society's system produces, and reproduces, is meaningful communication. This allows us to say that the legal system, as it is a system which is part of society, used as a way of operating communication, cannot do anything other than - as a means of meaning through communication - compose forms (sentences). It is the job of the social system to enable and make this evident in the course of a long socio-cultural evolution. In the legal system, this works as a guarantee that, for example, neither paper, nor ink, nor people, nor other bodies, nor in courts, nor in their spaces, nor telephones, nor computers, that are used there, are part of the system.

10 An example of this would be an environmental penalty that does not preclude the economic practice that generated environmental damage in the first place: despite being rejected by the legal system, the economic system does not necessarily refrain from doing it, due to its judgment on the profitability of the practice.

11 Niklas Luhmann, Theory of Society: volume 213 (Rhodes Barrett trans. Stanford University Press, 2013). 
two resulting cells consequently has operative autonomy within its own cell wall. This operative autonomy is the element that characterizes the operational closure of the system.

If we describe society as a system, it follows from the general theory of autopoietic systems that it must be an operationally closed one. At the level of the system's own operations there is no ingress to the environment, and environmental systems are just as little able to take part in the autopoietic processes of an operationally closed system. This is the case even, indeed especially, where such operations are observations or operations whose autopoiesis requires self-observation - a difficult thought that runs counter the entire epistemological tradition. ${ }^{12}$

Autonomy is the element that guarantees the systemic integrity of operations carried out within the system. Without autonomy, the communications of one system could overlap or conflict with those of another system. This would be considered a setback referred to as social dedifferentiation. "A imposição de um dos campos de linguagem aos outros importaria a própria destruição da heterogeneidade das esferas discursivas e dos respectivos sistemas de comunicação". ${ }^{13}$ An example of dedifferentiation would be if Religion and the State were to return to the prior situation of having less social differentiation, that is, if Religion were to begin operating within the defined operational limits of the State. Intersecting operations of different systems is referred to as communicational overlap. ${ }^{14}$

Communicational overlap often occurs in situations where specific economic interests are affected by the operations of other systems. An example of this is the pharmaceutical industry's modus operandi regarding patent protection and the exercise of exclusive rights over the products it develops. In this manner, health communication is replaced by profit communication. ${ }^{15}$ It is not by chance that the development of technological innovations resulting from the genetic editing of the human germline encounters similar pressure from the economic communication since that communication focuses on the paradox of scarcity which overlaps with the domain covered by the morality clause, as will be developed further in this text.

...ciência, esporte, religião. Todos estes âmbitos têm sua atuação limitada externamente pela escassez. O único sistema capaz de lidar com esse paradoxo é o econômico. Por isso, todos os outros sistemas pressupõem operações econômicas

12 Luhmann, supra note 6, at 49.

13 Marcelo Neves, Transconstitucionalismo 38 (Martins Fontes, 2009). Free translation: The imposition of one of the language fields on the others would imply the very destruction of the heterogeneity of the discursive spheres and the respective communication systems.

14 Salete Oro Boff, et al., Sistema de Patentes na Saúde: o sistema econômico sobrepondo-se à comunicação de saúde, in Propriedade Intelectual e Gestão da Inovação (Deviant, 2018).

15 Id. 
para poderem prosseguir. É o que Luhmann denomina interpenetração. Esses pontos precisam ser mais bem aclarados para que se compreenda toda a complexidade envolvida por qualquer operação social que lide com recursos escassos. ${ }^{16}$

Systemic evolution demonstrates the "autopoiesis" of Luhmann's theory. It is the process through which a system, within the limits of its operative closure and cognitive opening, either assimilates or rejects new elements and evolves as a result of that response. ${ }^{17}$ Systemic evolution is a process that takes place in three successive phases. These phases are: variation, selection, and re-stabilization. ${ }^{18}$

Variation is the phase of evolution through which points of provocation are perceived. These may be elements allowing for innovation, elements that are not stable within the current systemic structure, or elements that are no longer irrelevant to the communicational context within the system itself.

The recognition of these elements as variations is the first phase of systemic evolution. Since the environment outside any system has more complexity than the system itself, most variations tend to be perceived through systemic observation, that is, via the system's cognitive opening. Systemic variation is the aspect of the Autopoietic Systemic Theory that describes the process of technological innovation Human germline genetic editing is one such innovation which will be perceived as a variation inside the Social System, in both the economy and Law as systems.

Selection is the second phase of systemic evolution. In this phase, variations go through a process of either acceptance or rejection in relation to the internal context of the system. That is, selection is the process by which the system decides whether an element of variation will be treated differently in the future compared to the treatment it has received this far (if any at all), or how it will be treated if a difference is created in the process. One result could be a complete change of treatment from prohibition to permission, for example, as with a procedure such as abortion. Another possibility is that a plan to accommodate the variation will be developed for something that had not been previously considered by the system. An example of this is found in the juridical sphere where a new process had to be developed to deal with cyber crimes since no such process had previously existed. ${ }^{19}$ The juridical assessment as to whether

16 José Gladston Viana, Sociologia dos Direitos Sociais: escassez, justiça e legitimiDADE 68 (Saraiva, 2014). Free translation: science, sport, religion. All of these areas are limited externally due to scarcity. The only system capable of dealing with this paradox is the economic system. For this reason, all other systems presuppose economic operations in order to proceed. This is what Luhmann calls interpenetration. These points need to be better clarified in order to understand all the complexity involved in any social operation that deals with scarce resources.

17 Luhmann, supra note 6, at 275-276.

18 Luhmann, supra note 6, at 275-305.

19 It is important to note that selection by rejection of a variation is not the same thing as a situation where the variation has not been taken into account by the system at all. This is 
inventions such as human germline genome editing warrant intellectual property protection must be focused on how the morality clause should be applied in intellectual property cases.

Re-stabilization, the final phase of systemic evolution, has a paradoxically important role. Re-stabilization is the phase in which the selection of the variation is absorbed into the system's operational context and incorporated into its communicational code. However, even after the variation has been fully incorporated, an element of eccentricity persists. Systemic restabilization can never be fully complete because the restabilized element itself remains subject to further variation, which would trigger a renewed process of systemic evolution. This apparently paradoxical element of restabilization stems from the fact that the objective of systemic evolution is not the final resolution of a particular problem within the system, but rather, the operational perpetuation of the system itself via the adaptive mechanism of systemic evolution.

\section{Genetic Editing of the Human Genome AS AN IMPORTANT VARIATION}

Recent scientific advances in genetic editing have not fundamentally transformed or expanded the capabilities of editing processes. Rather, these innovations have typically involved reducing margins of error and increasing accessibility by dramatically reducing the cost of genetic editing tools. In fact, this is not unique to genetic engineering. In many fields, a simple advance, as predicted by Moore's law ${ }^{20}$ can lead to the rapid dissemination of new technologies. It could be said that the most significant socially observable innovations are those which result in increased accessibility, in terms of both cost and ease of access, to already existing technology rather than the creation of new technologies themselves.

Back in the 1980s, scientists had been content to edit individual genes at efficiencies that were just fractions of a percent. By the early 2000s, the efficiencies moved into the low-single-digit percentages, and it became possible to alter genes in a couple of new ways. ${ }^{21}$ But with CRISPR, gene editing was now so powerful and multifaceted that it was often referred to as genome engineering, a reflection of the supreme mastery that scientists held over genetic material inside living cells. ${ }^{22}$

\footnotetext{
because an explicit rejection of the variation will produce a systemic structural reaffirmation of the rejection for the variation itself.

20 Robert Schaller, Moore's law: past, present and future, 34 (6) IEEE SPECTRUM 52, 59 (1997).

21 The techniques alluded to here are ZFN (Zinc Finger Nuclease) and TALEN.

22 Jeniffer Doudna et al., A Grack in Creation, Gene editing and the unthinkable POWER TO CONTROL EVOLUTION 100 (Mariner Books, 2017).
} 
Early genetic editing techniques requiring access to extremely sophisticated and expensive research facilities as well as highly specialized scientists. The prohibitive costs associated with this research discouraged many laboratories that would otherwise have been interested in working with genetic editing techniques. ${ }^{23}$ The entry of CRISPR technology radically altered the range of possibilities for researchers. This technology is now so inexpensive that even high school students can practice genetic editing in laboratories with limited resources. In fact, complete kits for the genetic editing of bacteria are currently available to consumers for as little as US\$130. ${ }^{24}$

On June 8, 2012, an American biochemist at the University of California, Jennifer Doudna, after a one-year collaboration with French researcher Emmanuelle Charpentier, submitted the results of their work to the journal, Science. That work is now regarded as the first scientific work on the capabilities of genetic editing using the CRISPR tool. ${ }^{25}$ The work was accepted for publication on June 28, 2012, and published less than two months later on August 17, 2012. ${ }^{26}$ Early in the following year, on February 15, 2013, two related works were submitted to the same journal. One outlined the possibilities for the genetic engineering of eukaryotic cells, ${ }^{27}$ and the other described the editing procedure using CRISPR in cells. ${ }^{28}$

Following the publication of the first two scientific articles mentioned in the last paragraph, a patent dispute arose between the Broad Institute at MIT and the University of California. ${ }^{29}$ The dispute centered on the patent applications made to the USPTO (United States Patent and Trademark Office) by those two institutions. The Broad Institute claimed its patent application contained a specific description of performing genetic editing on eukaryotic cells, and that the patent application of the University of California only described the process in a general manner. ${ }^{30}$

The legal cause of action was the University of California's claim of "interference", 31 that is, that the patent granted to the Broad Institute en-

23 Ibid. at 111.

24 Id.

25 Ibid. at 85

26 Martin Jinek et al., A programmable dual-RNA-guided DNA endonuclease in adaptive bacterial immunity, 337 (6096) ScIEnce 816, 821 (2012).

27 Le Cong et al., Multiplex genome engineering using CRISPR/Cas systems, 339 (6121) SCIENCE 819, 823 (2013).

28 Prashant Mali, et al., RNA-guided human genome engineering via Cas9, 339 (6121) SCIENCE 823, 826 (2013).

29 The University of California is joined by the University of Vienna and Professor Emmanuelle Charpentier in this litigation. As a result, these parties to the litigation are often referred to collectively as "CVC" in court documents and news articles.

30 Heidi Ledford, Broad Institute wins bitter battle over CRISPR patents, 542 (7642) NAT. NEws, 401 (2017).

31 Id. 
croached on the patent granted to the University of California. On February 15, 2017, a three-judge panel from the Patent Trial and Appeal Board (PTAB) found in favor of the Broad Institute, and the University of California's subsequent appeal of that decision was denied by the US Court of Appeals for the Federal Circuit on September 10, 2018. ${ }^{32}$ However, litigation surrounding this dispute is ongoing due to the fact that the University of California filed a second interference claim against the Broad Institute. Proceedings in this related second case are still in the discovery phase, leaving many of the original issues unresolved. Nevertheless, several points raised by this case have extremely important economic implications for the field of genetic editing in general, one of which is significant for the present work:

The dispute centered on the rights to commercialize products developed by using the CRISPR-Cas9 system to make targeted changes to the genomes of eukaryotes - a group of organisms that includes plants and animals. Although many patents have been filed describing various aspects of CRISPR-Cas9 gene editing, the Broad Institute and UC patent applications were considered to be particularly important because they covered such a wide swath of potential CRISPR-Cas9 products. Investors have watched the case closely, even as they poured millions into companies that aim to develop medicines and crops using CRISPR-Cas9. The zeal with which both institutions defended their patents was unusual, says Jacob Sherkow, a legal scholar at New York Law School in New York City. Normally, he says, such institutions would settle out of court before the case reached this point. ${ }^{33}$

The intensity of the dispute demonstrates how the exclusive appropriation of a new technology through intellectual property mechanisms can be extremely valuable, especially a genetic editing tool that can be used to modify the human genome. Although the unit value of the tool itself would not seem to justify multimillion dollar investments of both public and private capital, the fact that it will be used on a massive scale explains why this technology would have great economic value to the patent holder.

On November 26, 2018, the announcement of the birth of Chinese twins whose CGR5 gene had been disabled by genetic engineering took the scientific community by surprise and led to immediate calls for a moratorium on hereditary genetic engineering applied to humans. ${ }^{34}$ The objective of $\mathrm{He}$ Jiankui, the scientist who performed the genetic editing of the zygote using CRISPR technology, was to make the children immune to the HIV. Although

32 Appeal from the United States Patent and Trademark Office, Patent Trial and Appeal Board, Case No. 106,048, 2018 (USA).

33 Heidi Ledford, Pivotal CRISPR patent battle won by Broad Institute, NATURE News, Springer Nature America, Inc (2018).

34 Eric Lander, et al., Adopt a moratorium on heritable genome editing, 567 NATURE 165, 168 (2019), available at $h t$ tps://doi.org/10.1038/d41586-019-00726-5. 
Jiankui's conduct was universally criticized, it must be pointed out that risky experimentation is not unprecedented in the history of not only medical practices, but of successful medical practices.

Perhaps the paradigmatic example of innovative tests being carried out at great risk to a patient's life due to unpromising forecasts of success is the case of Edward Jenner. Jenner invented the modern version of what we call a vaccine, an innovation responsible for the preservation of countless human lives (a reminder the world post-COVID-19 may find unnecessary). On May 14, 1796, Jenners injected an eight-year-old boy named James Phipps, with a known lethal pathogen, cowpox, which causes smallpox in humans, without any solid medical evidence that this would not lead to the boy's death. ${ }^{35} \mathrm{At}$ the time, Jenner was intensely criticized by the medical community and characterized as irresponsible for putting a child's life at risk based on a hunch, whereas today, he is regarded as a great discoverer, a hero of medicine. ${ }^{36}$ It is important to keep in mind that the moral condemnation of He Jiankui could also change over time.

His case is in such a way analogous to Jenner's that the success of his experiments and their side effects are highly uncertain and elude his ultimate control, making it a case of potential moral luck. Even though Jenner might not have crossed established ethics consensus, laws and regulations as obviously as $\mathrm{He}$ did, medicine in Jenner's century was not an "ethical wild West" either. ${ }^{37}$

Despite the possibility that Jiankui's achievement could eventually be regarded as a case of moral good luck, the immediate reaction of the scientific community was to call for a moratorium on hereditary genetic editing in humans. ${ }^{38} \mathrm{~A}$ moratorium is merely a request to postpone, in this case, to postpone the practice of hereditary genetic editing of the human genome. A moratorium was necessary, according to the text of the moratorium itself, ${ }^{39}$ due to the birth of the twins with genomes edited by CRISPR technology, and the lack of clarity in the declaration of the international summit on genetic editing ${ }^{40}$ when it comes hereditary genetic editing the human genome.

The moratorium calls for voluntary compliance. Its primary aim is raising awareness about the risks presented to society by Jiankui's experiment

35 Martin Sand, et al., After the fact-the case of CRISPR babies, EuropeAn Journal OF HuMAN Genetics 1, 4 (2019).

36 Id.

37 Id.

38 Lander, supra note 45.

39 Id.

40 David Baltimore, et al., On Human Gene Editing: International Summit Statement, NATIONAL ACAdemy of ScIENCES (2015), available at https://wwrenationalacademies.org/news/2015/12/on-human-gene-editing-international-summit-statement. 
and alerting the public to the fact that this type of practice may become inevitable in the coming years. ${ }^{41}$ The European Society of Human Genetics has endorsed the moratorium, and the consensus of the international scientific community is to respect it. ${ }^{42}$ It is important to highlight that the deadline proposed by the moratorium is five Years, ${ }^{43}$ which would delay introduction of this type of procedure into mainstream scientific practice until the year 2024. Some scientists, however, consider a five-year delay to be too conservative.

From a utilitarian perspective, no principled reasons exist to support a risk-averse "precautionary" delay on an early-use HGGM ${ }^{44}$ attempt. However, a modest delay would have pragmatic benefits, a notion that has been given added impetus by the recent news of an ethically questionable and apparently not entirely successful first attempt at HGGM. I suggest that utility will be maximized if we kickstart the next biomedical revolution by proceeding not immediately but within around 1-2 years to intervene in the human germline. ${ }^{45}$

It is important to note that the uses of genetic editing technology covered by the moratorium, ${ }^{46}$ and referred to by the author above, ${ }^{47}$ are very limited and only apply to cases in which preimplantation in vitro fertilization is not being used to prevent offspring from inheriting their parents' genetic diseases. The only difference between these two perspectives is their assessment of the reasonableness of the five-year waiting period. Whereas the moratorium considers five years to be reasonable, Smith claims it is not.

There are two points where technological innovations involving hereditary genetic editing will encounter a bottleneck due to an inevitable confrontation with the legal communication, that is, where the innovation is guaranteed to generate a response from the juridical system.

The first point of confrontation is related to scientific communication. Legal authorization will be required in order to conduct innovative research and to secure the exclusive rights to the use of new technologies guaranteed by the Intellectual Property schem. ${ }^{48}$ Given that human germline genome editing

41 Lander, supra note 45.

42 Sand, supra note 36 , at 1,4 .

43 Lander, supra note 35.

44 HGGM is an acronym for Human Germline Genome Editing.

45 Kevin Smith, Time to start intervening in the human germline? A utilitarian perspective, 34 (1) BIOETHICs 90, 104 (2020).

46 Lander, supra note 35.

47 Smith, supra note 46.

48 Even though CRISPR technology already enjoys patent protection, it is important here to discuss how innovations in general are dealt with by intellectual property institutions. Some innovations may be so unique that they require sui generis protection, but that is a subject beyond the scope of this work. 
research is already taking place, and that public selection of this technology will occur in the context of Intellectual Property legislation, this article will consider societal approval of an innovation to be the official authorization of Intellectual Property protection for that innovation.

The second point of confrontation will come from economic communication. This is the communication most likely to force the variation through the aforementioned bottleneck. In economic terms, since the surge in use of CRISPR genome editing technology in 2013, the market has been making massive investments in biotechnology. By 2014, the genetic editing market alone was worth US $\$ 1.84$ billion, ${ }^{49}$ and by the following year, biotechnology had become the second most well-financed sector in the United States ${ }^{50}$ And, as was shown above, the economic pressure behind the CRISPR technology has become so intense that it has even penetrated academia in the United States. Instead of working purely for the advancement of science and the free dissemination of knowledge, universities themselves are aggressively litigating their intellectual property rights in order to maintain their market positions and protect their exclusive rights to pursue potentially lucrative commercial opportunities and advantageous projects with eminent non-profit institutions. ${ }^{51}$

\section{The Meaning of Moral Glause AND AN EXAMPLE OF Glosure}

Morality is a term broadly defined as human judgment in relation to individual and social conduct. This judgment is typically derived from behaviors either condoned or disfavored by society as a whole, or by specific social groups within a Society. ${ }^{52}$ Morality, therefore, is an element that exists in human society as a mechanism for contextual, temporal, and spatial judgment, which derives from individual or collective rationality, and serves to approve or reject certain practices in the environment in which the judgment takes place.

We find on further enquiry that most, perhaps all, actual moral judgements are fairly closely correlated with what we may call social demands: any society or social group has regular ways of working, and, in order to maintain these, requires that its members should act in certain ways: the members - from whatever motive, perhaps mainly habit, which has compelled them to adapt

49 Katelyn Brinegar et al., The commercialization of genome-editing Technologies, 37 (7) CRITICAL Reviews in Biotechnology 924, 932 (2017).

$50 \mathrm{Id}$.

51 Knut Egelie et al., The emerging patent landscape of CRISPR-Cas gene editing technology, 34 (10) Nature Biotechnology 1025, 1031 (2016).

52 John Mackie, A refutation of morals, 24 (1-2) The Australasian Journal of Psychology AND Philosophy, 77-90 (1946). 
their desires to the established customs - obey these requirements themselves and force their fellows to do so, or at least feel obliged to obey and approve of others obeying. ${ }^{53}$

Human moral judgment is evolutionarily critical to maintaining the intensely social lifestyle that characterizes the human species ${ }^{54}$ in the same way that the evolution of moral thought within society tends to generate a complex system of norms endowed with cogency. ${ }^{55}$ Social complexification is typically accompanied by challenges to social stability. Morality alone is not a sufficiently solid institution on which to maintain a high level of social complexity, precisely because moral judgment lacks formality in its conception. It exists more as a judgment made based on a specific contextual evaluation rather than from an attempt to observe moral facts. ${ }^{56}$

From an historical perspective, the relationship between morality and law is one in which the complexification and formalization of morality gave rise to law as an object. ${ }^{57}$ From a social perspective, generalized moral judgments tend to become part of the legal system due to the fact that, ultimately, the legal system must adapt itself to social moral judgment. ${ }^{58}$ Two observations follow. First, morality has served, and continues to serve, as the origin of law, whether historically or socially. Second, in addition to the difference in the element of cogency, morality is more fluid and responds more quickly and easily to social judgment, without the need to alter structural formalities in the same way that occurs within the law. In the present work, this characteristic of morality will be referred to as dynamism.

Morality's dynamism is one of its most interesting characteristics, especially considering that legal institutions will sometimes use it as a justification when faced with the absence of formal, decision-guiding mechanisms on a particular subject. Moral judgment depends solely on societal reactions or expectations regarding specific behaviors, and is therefore subject to change. The flexibility of these judgments is only as formally bureaucratic as the change of opinion of human individuals.

Para apresentar a função normativa comum à moral e direito, pensemos numa sociedade sem nenhum tipo de autoridade pública, isto é, sem tribunais nem legisladores, onde o controle da vida social se exerceria somente pela atitude

53 Id.

54 William Allman, Stone Age Present: How Evolution Has Shaped Modern LifeFrom Sex, Violence and Language to Emotions, Morals and Communities 21 (Simon and Schuster, 1995).

55 Aluisio Schumacher, Sobre moral, direito e democracia, 61 LUA Nova: REVISTA DE CULTURA E POLÍTICA 75, 96 (2004).

56 Mackie, supra note 53.

57 Schumacher, supra note 56.

58 Id. 
geral do grupo em relação a seus próprios modelos de comportamento. Em tal contexto, práticas contrárias às expectativas sociais poderiam ser objeto de desaprovação. Assim, determinadas expressões faciais ou modalidades de linguagem corporal, com o uso, poderiam se consagrar como maneiras de censurar comportamentos, sendo aprendidas e mantidas de geração em geração. ${ }^{59}$

The moral clauses of various legal systems around the world often allow for decision-making on issues requiring authorization or prohibition without requiring formal amendment of the law. Legal changes can occur based solely on the change of the social assessment of the morality of a particular conduct, and at times, can even override clear legal commandments. This will be discussed further below. To illustrate this interplay between law and morality in the context of technological innovation, this article will examine the moral clause of the European Patent Convention.

According to the European Parliament, ${ }^{60}$ "The patent system encourages companies to make the necessary investments in innovation and encourages citizens and companies to devote resources to research and development." The institution charged with handling patent issues is the European Patent Office. The legislation that governs the granting of patents is the European Patent Convention. This is the legal text which will be analyzed here.

Due to its comprehensive scope, the European Patent Convention will serve the present work as a structural comparison for the related Mexican text. It is important to emphasize that the discussion here will address the appropriation of Intellectual Property, and will not be concerned with the morality of the innovations themselves. The focus will be on the morality of the commercial exploitation of these innovations and will employ the same terminology used by the European Patent Convention. ${ }^{61}$

In Article 53, the European Patent Convention ${ }^{62}$ lists the exceptions to patentability that must be considered by the European Patent Office when granting patents. The first exception identified by Article 53(a) is the moral patent-

59 Schumacher, supra note 56, at 75, 96. Free translation: To present the normative function common to morals and law, let us think of a society without any type of public authority, that is, without courts or legislators, where the control of social life would be exercised only by the general attitude of the group in relation to its own models of behavior. In such a context, practices contrary to social expectations could be objects of disapproval. Thus, certain facial expressions or body language modalities, with use, could become established as ways to censor behaviors, being learned and maintained from generation to generation.

60 European Parliament, Intellectual, industrial and commercial property (2019) available at https://wrwe.europarl.europa.eu/factsheets/en/sheet/36/propriedade-intelectual-industrial-ecomercial.

61 Viola Prifti, The limits of "ordre public" and "morality" for the patentability of human embryonic stem cell inventions, 22 (1-2) The Journal of World Intellectual Property 2, 15 (2019).

62 European Patent Office, The European Patent Convention. Convention on the Grant of European Patents (1973), available at https://wrere.epo.org/law-practice/legal-texts/ html/epc/2016/e/ma1.html. 
ability clause, which is a closed moral clause. The closure results from the fact that the morality issue is addressed in two different sections of that legislation. Article 53(a) of the Convention announces the morals clause, and Rule 28(1) of the Convention's Implementing Regulations explicitly references and further clarifies Article 53(a). Article 53(a) states: "European patents shall not be granted in respect of: (a) inventions the commercial exploitation of which would be contrary to "ordre public" or morality; such exploitation shall not be deemed to be so contrary merely because it is prohibited by law or regulation in some or all of the Contracting States". ${ }^{3}$

Article 53(a) identifies two issues of interest for the present work. The first is the way in which the exception addresses the law of the Contracting States to the European Patent Office. By emphasizing that patent protection will not be deemed contrary to public morality or "ordre public" 64 simply because it is prohibited in some or all of the Contracting States, the Convention effectively places the determination of morality and public order in the Convention itself, superior to the patent protection mechanisms of all signatory States. This grant of legal supremacy to the Convention in the area of patent protection has more to do with avoiding delays due to legislative bureaucracy than making an assessment of the social function of patents. ${ }^{65}$ Because patents facilitate the development of new technologies, and those new technologies serve to improve the quality of life of society as a whole, protection of inventions may serve the "ordre public" despite a prohibition by any individual signatory state. ${ }^{66}$

In the context of the Autopoietic Systems Theory, this means that the European moral clause gives the patent granting authority a moral opening that overlaps with the legal communications of all signatory states to the Convention. If Article 53(a) had not been clarified in Rule 28(1)(b), ${ }^{67}$ the resulting moral openness would have invited pressure from outside the juridical system to simply approve patent protection for human germline genome editing.

The second issue of interest is that Article 53(a) is interdependent with Rule 28(1) of the Convention's Implementing Regulations. Rule 28(1)(b) expressly prohibits the grant of patents for innovations in biotechnology which concern "processes for modifying the germ line genetic identity of human beings". ${ }^{68}$ This rule obviates the need for any juridical assessment of "morality" or "or-

\section{Id.}

64 The present work will not analyze the term "ordre public" beyond identifying it as a term used in the Convention which is considered an important element in the patent concession process. The term refers to patent grants that have the potential to generate public commotion and protest (Prifti, 2019, p. 5), a concern that can be interpreted as indicative of society's negative moral judgment in relation to concessions.

65 Prifti, supra note 62, at 2, 15.

66 Id.

67 European Patent Office, supra note 63.

$68 \mathrm{Id}$. 
dre public" by removing the entire subject matter of human germline genome editing from consideration. ${ }^{69}$ Thus, the morals clause is considered closed, meaning it is directly connected to the legislation's text only, and not by the moral opening that the clause generically has. ${ }^{70}$

One of the principal motivations for including a moral clause in legislation is the expectation of unpredictability, that is, the recognition that unanticipated issues will arise that may elude clear legal interpretation due to the Law's formality. Inflexibility can leave Intellectual Property laws incapable of preventing the development of potentially harmful inventions. An extreme example would be attempting to patent a means for committing genocide, or a technique whose implementation could result in great risk to society at large. When a new, complex variation triggers the morals clause, as is the case with human germline genome editing, a normative closing of the clause removes the moral judgment from the equation and predisposes the system toward prohibition. Such a closure fosters legal certainty by eliminating the possibility that decisions relating to selection of a variation will be based on a general moral statement which is open to interpretation. Closure allows interested parties to know that authorization can only occur by a change of the law.

Considering the legal closure of the moral clause contained in the European Patent Convention, it is possible to identify how the debate developed in the European Union. Despite the clear prohibition in the text of the European Patent Convention, there are strong indications that this prohibition has an expiration date. On May 9, 2019, the German Ethics Council published Press Release $03 / 2019^{71}$ which calls for a moratorium, but also encourages using various decision-making mechanisms to address the issue of genetic editing for both the prevention of hereditary diseases and for human improvement.

Last year, the birth of the first genetically modified babies shook the world. The German Ethics Council now presents a comprehensive ethical investigation into possible interventions in the genome of human embryos or germ cells. The Council does not deem the human germline to be inviolable. It does, however, consider germline interventions to be ethically irresponsible at the present time because of the associated incalculable risks. The Council, therefore, calls for an

69 Prifti, supra note 62, at 2, 15.

70 Rule 28(1)(b), by its own language, is limited to innovations that modify the "germ line genetic identity of human beings". It is possible that this language might still allow the European Patent Office to authorize patents for processes where the resulting genetic changes are not significant enough to be called a modification of the germline identity of human beings. This issue is, however, beyond the scope of this article.

71 German Ethics Council, PRESS RELEASE 03/2019, Ethics Council: germline interventions currently too risky, but not ethically out of the question, available at https://wrere. ethikrat.org/en/press-releases/2019/ethics-council-germline-interventions-currently-too-risky-but-not-ethi cally-out-of-the-question/. 
application moratorium and recommends that the Federal Government and the Bundestag work towards a binding international agreement. ${ }^{72}$

The German Ethics Council, the Deutscher Ethikrat, issued the aforementioned press release accompanied by a text expressing the opinion of the Council, as well as a decision tree and organizational chart through which all ethical issues related to the genetic alteration of the human germline must pass. ${ }^{73}$ This is noteworthy considering Germany is a country that does not prohibit basic genetic research involving stem cells derived from fetuses, yet does expressly prohibit the clinical application of such research, which includes implantation of these cells. ${ }^{74}$

As long as genetic research is being conducted, even when clinical application is not permitted, innovations continue to occur which can be appropriated and reserved through Intellectual Property mechanisms, even without the legal system explicitly granting these protections. As a result, when innovations do appear, it is possible they are kept under lock and key and will only become known to the public at some point in the future when they can be legally appropriated. In the meantime, the economic system, anticipating profit from the exclusivity rights the intellectual property scheme guarantees, will favor selection of the innovation and apply pressure on the legal system for its preference for prohibition based on either the closure constructed in the European system, or in the moral clause, where closures such as the aforementioned do not exist.

In Germany, the only type of genetic editing currently permitted for scientific research is genetic research involving somatic cells. ${ }^{75}$ Research on germline cells and the creation of fetuses for research purposes are both not only illegal, but a crime under German law. ${ }^{76}$ However, even somatic cell research can generate results useful to germline genetic editing, since a successful editing of any of the more than two thousand diseases directly linked to the human genome ${ }^{77}$ could be applied later to germline cells.

$72 I d$.

$73 \mathrm{Id}$.

74 Andrea Boggio et al., Towards a Human Rights Framework for the Regulation of Human Germline Genome Modification. Human Germline Genome Modification and the Right to Science: A Comparative Study of National Laws and Policies 4-5 (Andrea Boggio et al., ed., Cambridge University Press, 2019).

75 Timo Faltus, The Regulation of Human Germline Genome Modification in Germany, in Towards a Human Rights Framework for the Regulation of Human Germline Genome Modification. Human Germline Genome Modification and the Right to Science: A Comparative Study of National Laws and Policies 241 (Andrea Boggio et al., ed., Cambridge University Press, 2019).

76 Ibid. at 245.

77 Francisco José Ayala, ¿Clonar Humanos? Ingeniería genética y futuro de la humaNIDAD 103 (Alianza editorial, 2017). 
The issues raised by human germline genome editing, including the proposed moratorium, warrant intense public debate, ${ }^{78}$ and the process of legislative change would benefit from a specific and detailed decision-making scheme such as the synoptic table created by the German Ethics Council. ${ }^{79}$ Economic forces are able to apply a great deal of pressure on the legal system in their attempt to obtain approval for innovations related to the alteration of the human germline. However, the autonomy of the legal system will not be compromised as long as the legal system's operational limits are clearly closed.

The European Patent Convention contains a closed moral clause in a context where discussion regarding the appropriation of innovations relating to the manipulation of the human germline is in vogue. This is not necessarily the status quo in Latin American countries. The exercise of moral judgment by a society depends on the existence of a legal closure in the relevant legislation, as well as the capacity of its institutions to deal with unusual or controversial innovations. The case of Mexico will now be examined to determine how that country responds to innovations as a result of the moral clause contained in its Intellectual Property legislation.

\section{Open Moral Glause, the Mexican Example}

In Mexican legislation, the moral clause pertaining to industrial property is found in Article 4 of the Ley de la Propiedad Industrial. ${ }^{80}$ Similar to moral clauses in the laws of many other countries, but in contrast to that of the European Patent Office, the Mexican morality clause is not closed. It is an open, normative declaration. Article 4 reads: "No se otorgará patente, registro o autorización, ni se dará publicidad en la Gaceta, a ninguna de las figuras o instituciones jurídicas que regula esta Ley, cuando sus contenidos o forma sean contrarios al orden público, a la moral y a las buenas costumbres o contravengan cualquier disposición legal". ${ }^{81}$

Mexican social morality derives from its overwhelmingly Catholic Christian society, and moral determinations tend to follow Catholic morality. ${ }^{82}$ As a result, intellectual property protection for procedures related to human

78 Eric Lander, et al., Adopt a moratorium on heritable genome editing, NATURE Comment (2019), available at https://doi.org/10.1038/d41586-019-00726-5.

79 German Ethics Council, supra note 72.

80 Ley de la Propiedad Industrial [L. P. I.] [Industrial Property Law], as amended, Diario Oficial de la Federación [D.O.F], June 27th, 1991 (Mex.).

81 Id., Free translation: No patent, registration or authorization will be granted, nor will publicity be given in the Oficial Journal of the Federation, to any of the legal figures or institutions that regulate this Law, when its content or form is contrary to public order, morals and good customs or goes against any legal provision.

82 Elsa Guzmán et al., Back to Basics Mexican Style: Radical Catholicism and Survival on the Margins, 16 (3) Bulletin of Latin American Research 351, 366 (1997). 
germline genome editing tends to be rejected as contrary to Article 4. However, there is evidence that even when intense moral disapproval exists, given the excessive restraint of the Mexican legal system, the moral clause will yield to economic pressure.

The regulatory gaps in Mexican legislation have consequences for clinical science. While the moral clause of the industrial property law does not protect innovations in the field, and limits Intellectual Property rights in this area, the biotechnology regulations need improvement in terms of their responsiveness to questions regarding clinical and experimental use in Mexico. ${ }^{83}$

In fact, the lack of regulatory clarity has already led to numerous problems due to the resulting uncertainty about the limits of allowable research and clinical applications, particularly for institutions engaged in the research and development of new technologies who operate within the national territory. ${ }^{84}$ Mexico's GMO biosafety law, the Ley de Bioseguridad de Organismos Genéticamente Modificados, defines organisms for purposes of that law and specifically excludes human beings from that definition. The text of Subsection XX of Article 3 states:

XX. Organismo: Cualquier entidad biológica viva capaz de reproducirse o de transferir o replicar material genético, quedando comprendidos en este concepto los organismos estériles, los microorganismos, los virus y los viroides, sean o no celulares. Los seres humanos no deben ser considerados organismos para los efectos de esta Ley. ${ }^{85}$

By specifically excluding human beings from this legislation, Mexico has left a significant gap in its regulatory scheme relating to medical innovations. ${ }^{86}$ The result is that researchers enjoy a great deal of autonomy concerning biosafety issues related to human genome experimentation. In fact, even though Mexico has had a biosafety law governing GMOs since 2005, no legislation in that country made any mention of the human genome in its general health law, the Ley General de Salud, until a legislative amendment was added in $2011 .{ }^{87}$

83 Sarah Chan et al., Genome editing and international regulatory challenges: Lessons from Mexico, 2 (3) Ethics, Medicine and Public Health 426,434 (2016).

84 Id.

85 Ley de Bioseguridad de Organismos Genéticamente Modificados [L. B. O. G. M.] [GMO Biosecurity Law], as amended Diario Oficial de la Federación [D.O.F], March 18th, 2005 (Mex.). Free translation: XX. Organism: Any living biological entity capable of reproducing, transferring or replicating genetic material, including sterile organisms, microorganisms, viruses and viroids, cellular or not. Human beings are not to be considered organisms for the purposes of this Law.

86 César Palacios-González, et al., Mitochondrial replacement techniques and Mexico's rule of law: on the legality of the first maternal spindle transfer case, 4 (1) JOURNAL OF LAW AND THE BIOSCIENCES 50,69 (2017).

87 Ley General de Salud [L. F. S.] [General Health Law], as amended, Diario Oficial de la Federación, [D.O.F], February 7th, 1984 (Mex.). 
The 2011 amendment has eight entries under the heading "The Human Genome" (El Genoma Humano), and this is the extent of the treatment of the subject at the national level. ${ }^{88}$ At the state level, each Mexican state has its own health law, although the general law supersedes state laws where they overlap. ${ }^{89}$ The wide variation among state laws is partially responsible for the phenomenon of clinical tourism that has developed in Mexico. The aforementioned "Human Genome" provision of the Mexican general health law fails to clarify, or even specifically address, important elements critical to understanding the limits of permissible experimentation in this area.

While the GHA contains a section on "The Human Genome" (Título Quinto $\mathrm{Bis})$, this mainly concerns the uses of genetic information; genetic modification is not explicitly dealt with. As for the regulation of research on human embryos, gametes and stem cells, this has long been a contested area in Mexico; while the GHA and its associated regulations contain various provisions that might be interpreted to apply, they are very broadly framed, and hence the national regulatory framework remains unclear. ${ }^{90}$

This uncertainty has created an opening for the commercialization of various types of clinical treatments in the country, since the absence of prohibition has effectively created a de facto authorization. In Mexico, stem cell treatments without scientific proof of efficacy are advertised in the United States as "alternative treatments with stem cells not yet approved by the FDA". ${ }^{91}$ This is an example of how the country has become a destination for clinical tourism of unscientific procedures.

Clinical tourism in Mexico reached its mediatic apex when the first baby in the world with genetic material inherited from three different parents was born on April 6, 2016. ${ }^{92}$ This experimental procedure was performed by Dr. John Zhang. Zhang had previously practiced in the United States, but, due to the unreceptive regulatory environment there, he transferred his entire embryonic implantation operation to Mexico. ${ }^{93}$ Similar restrictions were also in place at that time in England where he had previously studied. ${ }^{94}$

88 Palacios-González, supra note 87, at 50,69.

89 Id.

90 Chan, supra note 84.

91 María de Jesús Medina, The Rise of Stem Cell Therapies in Mexico: Inadequate Regulation or Unsuccessful Oversight? 63 Revista RedBioÉtica/UNESCO 63, 78 (2012).

92 Palacios-González, supra note 87, at 50, 69.

93 María de Jesús Medina Arellano, The Regulation of Human Germline Genome Modification in Mexico, in Towards a Human Rights Framework for the Regulation of Human Germline Genome Modification. Human Germline Genome Modification and the Right to Science: A Comparative Study of National Laws and Policies 129 (Andrea Boggio et al., ed., Cambridge University Press, 2019).

94 Palacios-González, supra note 87, at 50, 69. 
Zhang's procedure employed a technique called mitochondrial replacement. ${ }^{95}$ The genetic material inherited by the child was not nucleic material, but rather specific genetic material of the mitochondria itself. ${ }^{96}$ Zhang elected to use this procedure due to the fact that the couple seeking his help had previously experienced the death of two of their children, an eightmonth old baby and a six-year-old child. ${ }^{97}$ Both children had died as a result of "Leigh's syndrome", a neurological disorder directly linked to mitochondrial DNA. ${ }^{98}$

Mexico's regulatory ambiguity affects a wide range of clinical procedures, not just those as sophisticated as mitochondrial replacement. Even assisted reproduction procedures encounter regulatory gaps in the country's legislation:

A consequence of the lack of specific regulation concerning assisted reproduction is that, at the federal level, no organization or authority regulates, evaluates, and compiles information about the way in which ARTs are carried out in Mexico, or the persons who carry them out. It also means, among other things, that there is no legal certainty about what kind of information should be collected for epidemiological and legal purposes, and the length of time that gametes and embryos should be stored. In terms of actual clinical practice, the Mexican Association of Reproductive Medicine and the Latin American Network of Assisted Reproduction (RedLara) - among other professional bodies - provide recommendations and regulations relating to the practice of assisted reproduction in Mexico. Nonetheless, clinics that offer assisted reproductive services follow their recommendations and regulations only on a voluntary basis. ${ }^{99}$

There is no internal legislation in Mexico, nor is there any international treaty to which Mexico is a signatory, that expressly prohibits the genetic editing of the human genome, be it somatic or germinal. ${ }^{100}$ This lax legal environment tends to foster clinical tourism, and economic actors in the genetic editing market could potentially take further advantage of this opening in the future.

These types of open moral clauses have a high likelihood of yielding to the economic communication, which prefers selection of the new technology and the Intellectual Property protections that accompany it. Recognition of two important points may assist countries like Mexico in forestalling this eventuality. First, the legal system does, in fact, have control over the open-

95 The mitochondria is a cellular organelle whose role is to generate energy for the cell and which carries genetic information in the form of mitochondrial DNA.

96 Palacios-González, supra note 87, at 50, 69.

97 Id.

98 Sanna Matilainen et al., Defective mitochondrial RNA processing due to PNPT1 variants causes Leigh syndrome, 26 (17) Human MOLECULAR GENETICs 3352, 3361 (2017).

99 Palacios-González, supra note 87, at 50, 69.

100 Id. 
ness of the morals clause itself, at least as it relates to facilitating decisionmaking in relatively simple cases. Second, the state has a duty to specifically address the issue of human germline genome editing in a responsible and robust manner.

Action on these issues is necessary not only to resolve the ethical issues raised by the science surrounding the genetic editing of human beings, but also to avoid falling behind other countries in this field, both technologically and economically. Inadequate regulation could lead to international disapproval or even liability, but strict prohibition could impede the country's ability to compete in the global market.

\section{Conclusion}

The question posed at the outset of this article ${ }^{101}$ required the resolution of two preliminary issues. The first issue was relatively simple, that is, whether morality alone is a sufficient basis on which to organize a complex society. The discussion presented in Section 4 revealed that morality alone is not a sufficient basis.

The second issue is one that carried with it a bit more complexity. That issue was whether human germline genome editing technology is so complex that it requires more explicit regulation than moral clauses are able to provide. Considering the evidence presented in Section 3, human germline genome editing has been shown to be a very sophisticated technology whose use raises significant and complicated ethical issues. As a result, the conclusion is that this technology does require detailed and unambiguous regulation.

A comparison of the language of the European Patent Convention in Section 4 with the related Mexican patent law provisions discussed in Section 5 reveals that a lack of closure in moral clauses promulgated by juridical systems can pose significant dangers. The Autopoietic Systems Theory demonstrated its usefulness by helping guide the analysis toward this conclusion. That theory revealed how systems with competing interests within a society use their communications to further their own interests, and how those communications themselves can trigger responses from other systems, adding a additional layer of complexity to the decision-making process.

Although moral clauses are useful and can be of great assistance in many cases, their limitations become apparent when confronted with complex and predictable issues. With a technology that messes with such a potent concept as human germline genome editing, it would be prudent to first ascertain whether the moral clause of the juridical system under consid-

101 Is it possible to verify whether the lack of closure of a morals clause in patent law, particularly when referring to human germline genome editing, acts merely as a general clause of prohibition that, in practice, fails to function as a moratorium? 
eration is open or closed, as this may be the main factor determining its effectiveness for mechanisms of juridical decision. Thus, the hypothesis originally posed in this article is confirmed. It has been shown that the lack of closure of a moral clause in patent law, especially as it relates to human germline genome editing, fails, in practice, to operate as a moratorium in countries like Mexico. 